\section{The Development of Private Higher Education in Turkey} Kemal Gürüz

Kemal Gürüz is former president of the Council of Higher Education of Turkey.E-mail:kguruz@po.metu.edu.tr.

A country with a young demographic profile, Turkey continues to experience an increasing demand for higher education, which the state institutions have been unable to meet. This article describes the factors that in the past have impeded the development of private higher education in Turkey, the private sector's present structure and place in the national system, and some of the major problems currently faced.

\section{Historical BACKGROUND}

The Republic of Turkey was born out of the ashes of the Ottoman Empire. But, leaving aside the professional "higher schools" founded in the Igth century, present-day Turkish universities did not evolve from the previously existing Islamic institutions of higher learning. Rather, the university as an institution was transplanted from the West by the young republic to replace the madrasa. Thus, for many years, universities were regarded as state institutions and the provision of higher education as part of public service. This is still the prevalent view in Turkey's highly egalitarian society, with an important bearing on the governance of Turkish universities as well as on the development of private higher education. The election of rectors and deans by the faculty has come to be considered a sine qua non policy for university autonomy and academic freedom.

The historical exception was Robert College in Istanbulthe first American institution of higher education outside the United States, founded in I863. In I956, Middle East Technical University (METU) was founded, modeled after American state universities with rectors and deans appointed by a lay board.

\section{FOR-PROFIT INSTITUTIONS IN THE 1960s}

With the development of a vibrant free-market economy and a growing population, the then existing institutions of higher education failed to meet the rapidly increasing demand; the gross enrollment rates remained a meager 4 percent during the ig6os. The vacuum was soon filled by some 50 for-profit institutions, in which enrollments rapidly reached 50,000. In I971, these institutions were ruled as unconstitutional and were incorporated into the existing polytechnics. Robert College, too, was transformed into a state university in I97I. Similar legal arguments based on the traditional view of higher education were cited in various rulings of the Supreme Constitutional Court in the I970s in abolishing the powers of the METU Board of Trustees and those of the Council of
Higher Education. The council had first been established in I973 as a nationwide coordinating body, in response to the rapidly increasing demand.

\section{Present Structure}

In I98I, new legislation was enacted that radically altered the higher education scene in Turkey. The Council of Higher Education was reconstituted as a national board of governors with powers to nominate candidates for rectorships and to appoint deans. In addition, the establishment of nonprofit institutions of higher education was permitted. However, it took several years before the first private institution, Bilkent, could use the title "university," because the Supreme Constitutional Court ruled that the constitution allowed private ones only to be named "institutions of higher education," not "universities." The legal dilemma was resolved by enacting a separate founding legislation for each and every one of the private universities and giving each of them "corporate public body" status.

\section{Growth in EnROLLMENTS}

In the past two decades, 24 new private universities have been founded, and they now comprise the unified higher education system in Turkey, along with 53 state universities. Total enrollments in private universities have now risen from only 426 in I986 to 9I,000, constituting 4.3 percent of the total enrollments of 2.I million students. Distance education is provided by one state university, Anadolu University, with about 700,000 students. Thus private enrollments are 6.5 percent of the total full-time enrollments, those in bachelor's-level programs compose 5.0 percent of the total, while the corresponding rates for associate, master's, doctoral, and medical pro-

With the development of a vibrant free-market economy and a growing population, the then existing institutions of higher education failed to meet the rapidly increasing demand.

grams are 2.2, 8.7, 3.9, and 2.9 percent, respectively. Institutitonal size, in terms of student enrollments, varies from about 300 in the newly founded universities to 13,000 in the largest one, Yeditepe University (founded in I996), and II, ০০o in Bilkent University, the oldest one.

The total number of full-time faculty at private universities is presently 7,000-corresponding to 8.3 percent of the system's total of 82,000 academic staff. In general, students admitted to private universities have comparatively lower scores on the central admissions examination-mainly because the majority of students prefer to study at the much cheaper state universities, which in general provide as good and, in many cases, better education and facilities. However, the situation differs somewhat among the first roo and the 
first I,, 00 of top-scoring students on the admissions examination. Fierce competition exists among leading state universities and the more prestigious private universities to attract as many of the students in that range as possible. The latter universities, however, have an unfair advantage given their ability to lure students by providing generous scholarships.

Many private universities function mainly as teaching institutions, although a smaller number of them aspire to become world-class research universities. In 2004, Turkish academics published a total of over I4,000 articles in refereed journals covered by the Science Citation Index, Social Science Citation Index, and the Arts and Humanities Citation Index; I, ০০o of these articles were authored by faculty members at private uni-

Many private universities function mainly as teaching institutions, although a smaller number of them aspire to become world-class research universities.

versities. On the basis of publications per individuals, three private universities outperformed the best-performing state university.

Graduates of Turkish universities, both state and private, have no problem in being admitted to graduate programs at prestigious institutions worldwide. Publications by Turkish academics presently account for I.3 percent of the worldwide total, up from 0.067 percent in I98I, and already at least six state and three private Turkish universities are internationally recognized for the quality of their research activity. Further development in this area, however, will depend largely on the transformation of the national economy to a knowledge- and innovation-based structure.

\section{The Im pact of Private Universities}

In terms of both the number of institutions and the share of total enrollments, private higher education in Turkey falls way below the numbers commonly encountered in the Asia-Pacific rim, Latin America, and Central and Eastern Europe. Yet, the growth of private higher education in Turkey has been smooth and scandal free. The reasons for this line of development are the statutes that require all private institutions, governed by individual boards of trustees and completely autonomous in financial and administrative matters (including setting tuition fees and salary scales and appointing rectors and deans), to comply with the academic requirements set forth by the Council of Higher Education. This system entails student admissions through the central admissions system, based on a competitive student selection and placement examination, and the requirement that at least io percent of students must be admitted on scholarships provided by the institutions themselves. Private universities are eligible for state funding for up to half the per student funding at state universities. However, to qualify for such state aid, private institutions must demonstrate performance at par with state universities. The Council of Higher Education closely monitors the situation by measuring the numbers of students and publications per full-time faculty.

Private universities have contributed only slightly to overcoming the chronic supply-and-demand imbalance in Turkey. In their initial stage of development, these institutions have recruited faculty from the state universities and have relied on part-time staff. Many of these universities continue to do so, but a number have also been quite successful in repatriating Turkish academics and recruiting foreign staff.

The positive impact of private universities has been the creation of a competitive and entrepreneurial environment in an area still considered by many in Turkey to be the public domain. This shift, however, has come at cost to private universiites and may impede their further development. Given the archaic and restrictive laws, rules, and regulations pertaining to public financing, state universities basically lack the legal instruments of decision-making powers that would allow them to compete with private universities in the country, as well as with the various types of international providers that are constantly eyeing the lucrative Turkish higher education market. The resentment against private universities felt by many academics and administrators at state universities is a real threat to the establishment of a fair competition and can create an obstacle to further development of private higher education in Turkey. This is perhaps one of the important lessons that should be drawn from the Turkish experience: there must be a level playing field for all types of institutions and providers if a truly free and fair competitive market is to survive.

\section{New Private Sectors}

IHE devotes a column in each issue to a contribution from PROPHE, the Program for Research on Private Higher Education, headquartered at the University of Albany. See http://www.albany.edu/dept/eaps/prophe/.

T mpressed by a previously unnoticed comparative tendency In private higher education, PROPHE presents this special IHE section on new private sectors. The term new private sector refers here to private sectors that emerge subsequent to existing private sectors or after their demise. At least in the case of countries where the old private institutions survive, the new privates tend to be much more private in their finance, governance, and market missions; they may be functionally or even legally for-profit. In contrast, the old privates may in fact be viewed as part of the public sector for certain purposes. 